\title{
Entrepreneurship From Opportunity Discovery to Judgment
}

Foss, Nicolai Juul; Klein, Peter G.

Document Version

Final published version

Publication date:

2008

License

CC BY-NC-ND

Citation for published version (APA):

Foss, N. J., \& Klein, P. G. (2008). Entrepreneurship: From Opportunity Discovery to Judgment. Center for Strategic Management and Globalization. SMG Working Paper No. 5/2008

Link to publication in CBS Research Portal

\section{General rights}

Copyright and moral rights for the publications made accessible in the public portal are retained by the authors and/or other copyright owners and it is a condition of accessing publications that users recognise and abide by the legal requirements associated with these rights.

\section{Take down policy}

If you believe that this document breaches copyright please contact us (research.lib@cbs.dk) providing details, and we will remove access to the work immediately and investigate your claim. 
ENTREPRENEURSHIP: FROM OPPORTUNITY DISCOVERY TO JUDGMENT

\author{
Nicolai J. Foss \\ Peter G. Klein
}

SMG WP 5/2008

January 29, 2008 
SMG Working Paper No. 5/2008

January 29, 2008

ISBN: 978-87-91815-18-8

Center for Strategic Management and Globalization Copenhagen Business School

Porcelænshaven 24

2000 Frederiksberg

Denmark

www.cbs.dk/smg 


\title{
ENTREPRENEURSHIP: FROM OPPORTUNITY DISCOVERY TO JUDGMENT
}

\author{
Nicolai J. Foss \\ Center for Strategic Management and Globalization \\ Copenhagen Business School \\ Porcelainshaven 24 \\ 2000 Frederiksberg, Denmark \\ njf.smg@cbs.dk \\ Peter G. Klein \\ Contracting and Organizations Research Institute \\ University of Missouri \\ 135 Mumford Hall \\ Columbia, MO 65211 USA \\ kleinp@missouri.edu \\ January 29, 2008 \\ Word count (main body): 7,418
}

\section{ACKNOWLEDGMENTS}

This paper is a draft of Chapter 2 of our book Entrepreneurial Judgment and the Theory of the Firm (Cambridge: Cambridge University Press).

JEL CODES: B21, B53, L26. 


\title{
ENTREPRENEURSHIP: FROM OPPORTUNITY DISCOVERY TO JUDGMENT
}

\begin{abstract}
Entrepreneurship has become a fast-growing subfield in management research, and is increasingly appearing in economics, finance, and even law. We survey a number of approaches to entrepreneurship in the economics and management literatures, and argue that modern research in this area need to be focused around ideas from Austrian economics and Frank Knight on entrepreneurial judgment. We critically discuss the recent opportunity discovery literature in management, and argue that it has partially misunderstood the Austrian origins of the theory, and fails to adequately distinguish between opportunity identification and opportunity exploitation.
\end{abstract}

KEYWORDS: Theories of entrepreneurship, judgment, opportunity discovery. 


\section{INTRODUCTION}

Entrepreneurship is one of the fastest-growing subfields in management research, and is increasingly appearing in economics, finance, and even law. Entrepreneurship became a Division (specialized interest group) within the Academy of Management in 1987 and will soon have its own subject code in the Journal of Economic Literature classification scheme. Research and policy organizations such as the World Bank, the U.S. Federal Reserve System, and the U.S. Department of Agriculture show a growing interest studying and encouraging entrepreneurship. The Kauffman Foundation has substantially increased its funding for entrepreneurship research.

Entrepreneurship is also becoming one of the most popular subjects at U.S. colleges and universities (Gartner and Vesper, 2001; Solomon, Duffy, and Tarabishy, 2002). Entrepreneurship courses, programs, and activities are emerging not only in schools of business, but throughout the curriculum. In 2003 U.S. colleges and universities offered over 2,200 entrepreneurship courses at over 1,600 schools, supported by 277 endowed faculty positions, several dozen refereed academic journals, and more than 100 funded centers (Kuratko, 2003). While the field remains a minority specialization among business school faculty (Katz, 2003), during the 1990s the number of entrepreneurship positions increased by over $250 \%$ and the number of candidates nearly doubled (Finkle and Deeds, 2001). Besides the usual business school offerings courses in Social Entrepreneurship, Family Business Management, Technical Entrepreneurship, Performing Arts Entrepreneurship, and the like are popping up in colleges of arts and sciences, engineering, education, social work, and even fine arts.

Surprisingly, while the entrepreneur is fundamentally an economic agent-the “driving force of the market,” in Mises’s (1949, p. 249) phrase-modern economics 
maintains an ambivalent relationship with entrepreneurship. It is widely recognized that entrepreneurship is somehow important, but there is little consensus about how the entrepreneurial role should be modeled and incorporated into economic theory. Indeed, the most important works in the economic literature on entrepreneurship-Schumpeter's account of innovation, Knight's theory of profit, and Kirzner's analysis of entrepreneurial discovery—are viewed as interesting, but idiosyncratic insights that do not easily generalize to other contexts and problems. Because the entrepreneur in many ways personifies market forces, one might expect him to be the central figure in economics. Similarly, because most entrepreneurial ventures somehow involve a firm, entrepreneurship would seem to be a central subject in the economic theory of the firm.. However, one seeks in vain for references to the entrepreneur in the leading textbooks and research articles on the theory of the firm.

Similarly, the strategic-management literature has not had a strong role for the entrepreneur. (Within the Academy of Management, the Entrepreneurship interest group is separate from the Business Policy and Strategy and Organization Theory groups.) And yet, entrepreneurship is ultimately the main source of value creation at the firm level. Indeed, the firm’s key strategic decisions_-strategy formulation, market analysis, industry positioning, diversification, vertical integration and outsourcing, organizational design-are ultimately entrepreneurial decisions (Foss and Klein, 2002; Yu, 2005; Matthews, 2006) But it is only very recently that the strategic management field has realized the need for a closer relationship with entrepreneurship, resulting in the 2008 start-up of the Strategic Entrepreneurship Journal. The fields of organizational behavior and human-resource management may follow suit. 
The absence of the entrepreneur in economics and management is largely a product of the historical development of economics. While classical economists such as Adam Smith and, particularly, Jean-Baptiste Say gave the entrepreneur a central role in their accounts of the market process, this is hardly characteristic of modern economics. ${ }^{1}$ The historian of economic thought Paul McNulty (1984: 240) notes that

The perfection of the concept of competition . . . which was at the heart of the development of economics as a science during the nineteenth and early twentieth centuries, led on the one hand to an increasingly rigorous analytical treatment of market processes and on the other hand to an increasingly passive role for the firm.

The "increasingly rigorous analytical treatment" of markets, notably in the form of general equilibrium theory, not only made firms increasingly "passive," it also made the model of the firm increasingly stylized and anonymous, doing away with those dynamic aspects of markets that are most closely related to entrepreneurship (O’Brien 1984). In particular, the development of what came to be known as the "production function view" (Williamson, 1985; Langlois and Foss 1999)—roughly, the firm as it is presented in intermediate microeconomics textbooks with its fully transparent production possibility sets - was a deathblow to the theory of entrepreneurship in the context of firm organization. If any firm can do what any other firm does (Demsetz 1991), if all firms are always on their production possibility frontier, and if firms always make their equilibrium choices of input combinations and output levels, then there is no room for entrepreneurship. Even in more advanced models of asymmetric production functions, hidden characteristics, and strategic interaction, firms or agents are modeled as behaving according to

\footnotetext{
${ }^{1}$ As Machovec (1995: 109) notes, to the classical economists "specialization and commercial freedom spawned opportunities for alert individuals." Unlike later economists, the classical economists held what is essentially a process view in which competition was seen "as a tapestry of aggressive commercial behaviors which created pure profits by speculating on price futures, engineering new methods of production, and inspiring new product lines to better serve consumers" (ibid.: 136).
} 
fixed rules subject to formalization by the analyst. The entrepreneur makes an occasional appearance in business history and in Schumpeterian models of innovation and technical change, but is largely absent from contemporary economic theory.

Given this historical development, it is not surprising that much of the important work on the economics of entrepreneurship was done prior to this period (e.g., Schumpeter, 1911), and that more recent work by economists on entrepreneurship has been done largely outside of the confines of mainstream economics (e.g., Kirzner, 1973, 1979, 1985). There have been some attempts to incorporate aspects of entrepreneurship into traditional models—via equilibrium models of the self-employment decision (Kihlstrom and Laffont, 1979; Lazear, 2004), the choice of new-venture creatiopn (Holmes and Schmitz, 2001), or the R\&D investment decision (Aghion and Howitt, 1992). ${ }^{2}$ But these models treat entrepreneurship in a highly stylized and abstract fashion, not clearly distinguishing entrepreneurship from “management” or other economic functions.

Moreover, large parts of strategic management (especially the "UCLA" version of the resource-based view of the firm (Lippman and Rumelt, 1982; Barney, 1991; Peteraf, 1993) are based on the neoclassical competitive model and on the production-function view of the firm (if perhaps patched up in various ways) (Foss, 2003). Penrose's (1959) approach to firm capabilities and firm growth, by contrast, shares more with Austrian and evolutionary concepts of the firm and market than with neoclassical economics (Foss, Klein, Kor, and Mahoney, 2008), though the "real” Penrosian model, rather than the resource-based interpretation of Penrose (Barney, 1991; Peteraf, 1993), remains in the mi-

\footnotetext{
${ }^{2}$ See Bianchi and Henrekson (2005) for a review of attempts to incorporate entrepreneurship into neoclassical models.
} 
nority within mainstream strategic management. ${ }^{3}$ It is thus not surprising that it has been difficult to define a role for the entrepreneur in strategic management theory.

By contrast, the Austrian school of economics has always given the entrepreneur a central role in the economy, going back at least to the proto-Austrian contribution of Richard Cantillon (1755). ${ }^{4}$ For this reason, one would expect Austrian economics to figure prominently in the modern entrepreneurship literature. However, this is not the case. While Kirzner's concept of "alertness” is frequently invoked in particular strands of the entrepreneurship literature, particularly in management (e.g., Shane, 2003) this literature tends to misunderstand fundamentally the nature and purpose of Kirzner's metaphor of entrepreneurial discovery. Moreover, the overall causal-realist account of the market process that characterizes the Austrian approach has had little impact on contemporary entrepreneurship scholarship, which takes its underlying economic framework from the neoclassical account of production and exchange.

We argue that Austrian economics provides a natural foundation for entrepreneurship research, but not through the well-known Austrian concepts of distributed, tacit knowledge and entrepreneurial discovery. Rather, we maintain that entrepreneurship can be more thoroughly grounded, and more closely linked to the economic theory of the firm and the strategic-management literature, by adopting the Cantillon-Knight-Mises understanding of entrepreneurship as judgment, along with the Austrian's subjectivist account of capital heterogeneity. Our overall approach below is to ask if, and how, the entrepreneur needs a firm. The answers are not obvious. Some approaches to entrepreneurshipSchumpeter's concept of the entrepreneur as innovator, for instance-treat the entrepre-

\footnotetext{
${ }^{3}$ On the differences between Penrose and mainstream strategy thinking, see Foss (2000).

${ }^{4}$ On Cantillon's place in the Austrian tradition see the Fall 1985 issue of the Journal of Libertarian Studies along with Hayek (1931), Rothbard (1995, chapter 12), and Thornton (1998).
} 
neur as an uncaused cause, a pure genius who operates outside the usual constraints imposed by resource owners and other market participants and is thus unaffected by the firm. Other approaches treat entrepreneurs as skilled managers, exercising their entrepreneurial talents through skillful arrangements of productive factors, thus being an integral part of the firm's operation. ${ }^{5}$ We also critically discuss new developments in the entrepreneurship field in management, notably the tendency to identify entrepreneurship with opportunity discovery, arguing that this literature misinterprets Kirzner's instrumental use of the discovery metaphor and mistakenly makes "opportunities” the unit of analysis. Instead, we propose an alternative approach in which investment is the unit of analysis and link this approach to Austrian capital theory.

\section{CONCEPTS OF ENTREPRENEURSHIP AND THE FIRM}

\section{Entrepreneurship: Occupational, Structural, and Functional perspectives}

The remainder of this chapter reviews the economics and management literatures on entrepreneurship, critiques the dominant "opportunity-discovery” approach, and outlines a new synthesis of entrepreneurship and theory of the firm. We begin by organizing the various strands of entrepreneurship literature, distinguishing among occupational, structural, and functional perspectives.

Occupational theories define entrepreneurship as self- employment and treat the individual as the unit of analysis, describing the characteristics of individuals who start their own businesses and explaining the choice between employment and selfemployment (Kihlstrom and Laffont, 1979; Shaver and Scott, 1991; Parker, 2004). The labor economics literature on occupational choice, along with psychological literature on

\footnotetext{
${ }^{5}$ On the history of the entrepreneurship concept in economic theory, see Elkjaer (1991) and Ibrahim and Vyakarnam (2003).
} 
the personal characteristics of self-employed individuals, fits in this category. For example, McGrath and MacMillan (2000) argue that particular individuals have an "entrepreneurial mindset” that enables and encourages them to find opportunities overlooked or ignored by others (and that this mindset is developed through experience, rather than formal instruction).

Structural approaches treat the firm or industry as the unit of analysis, defining the “entrepreneurial firm” as a new or small firm. The literatures on industry dynamics, firm growth, clusters, and networks have in mind a structural concept of entrepreneurship (Aldrich, 1990; Acs and Audretsch, 1990; Audretsch, Keilbach, and Lehmann, 2005). Indeed, the idea that one firm, industry, or economy can be more "entrepreneurial" than another suggests that entrepreneurship is associated with a particular market structure (i.e., lots of small or young firms).

By contrast, the classic contributions to the economic theory of entrepreneurship from Schumpeter, Knight, Mises, Kirzner, and others model entrepreneurship as a function, activity, or process, not an employment category or market structure. The entrepreneurial function has been characterized in various ways: judgment (Cantillon, 1755; Knight, 1921; Casson, 1982; Langlois and Cosgel, 1993; Foss and Klein, 2005), innovation (Schumpeter, 1911), adaptation (Schultz, 1975, 1982), or alertness (Kirzner, 1973, 1979, 1992). In each case, these functional concepts of entrepreneurship are largely independent of occupational and structural concepts. The entrepreneurial function can be manifested in large and small firms, in old and new firms, by individuals or teams, across a variety of occupational categories, and so on. By focusing too narrowly on selfemployment and start-up companies, the contemporary literature may be understating the role of entrepreneurship in the economy and in business organization. 
What is the entrepreneurial function? Consider these possibilities: management; imagination or creativity; innovation; alertness; the ability to adjust; charismatic leadership; and judgment.

\section{Entrepreneurship as Management}

In the entrepreneurship curriculum of many business schools, the phenomenon under investigation has often been "small-business management."6 Entrepreneurs are pictured as the managers of small, family-owned businesses or start-up companies. Entrepreneurship consists of routine management tasks, relationships with venture capitalists and other sources of external finance, product development, marketing, and so on. In this sense, entrepreneurship and the theory of the firm — the theory of some firms, at least — are inextricably linked. The theory of entrepreneurship in this approach is the theory of how small business owners organize and manage their assets.

Unfortunately, this notion of entrepreneurship is sufficiently elastic to be practically meaningless. It appears to include virtually all aspects of small or new business management, while excluding the identical tasks when performed within a large or established business. Put differently, if entrepreneurship is simply a set of management activities, or any management activity that takes place with in a particular type of firm, then it is unclear why we should bother to add this label to those activities.

\section{Entrepreneurship as Imagination or Creativity}

It is common, particularly within the management literature, to associate entrepreneurship with boldness, daring, imagination, or creativity (Begley and Boyd, 1987;

\footnotetext{
${ }^{6}$ However, this appears to be slowly changing towards a more generic and theoretically based understanding of entrepreneurship.
} 
Chandler and Jansen, 1992; Aldrich and Wiedenmayer, 1993; Hood and Young, 1993; Lumpkin and Dess, 1996). These accounts emphasize the personal, psychological characteristics of the entrepreneur. Entrepreneurship, in this conception, is not a necessary component of all human decision-making, but a specialized activity that some individuals are particularly well equipped to perform. ${ }^{7}$

If these characteristics are the essence of entrepreneurship, then entrepreneurship has no obvious link to the theory of the firm (or, at least not without further arguments). The relevant personal characteristics can presumably be acquired by contract on the market by purchasing consulting services, project management, and the like. A "nonentrepreneurial” owner or manager, in other words, can manage the day-to-day operations of the firm, purchasing "entrepreneurship" on the market as needed. Moreover, the literature does not explain clearly whether imagination and creativity are necessary, sufficient, or incidental conditions for entrepreneurship. Clearly the founders of many firms are imaginative and creative. If not, are they not entrepreneurs?

\section{Entrepreneurship as Innovation}

Probably the best-known concept of entrepreneurship in economics is Joseph Schumpeter's idea of the entrepreneur as innovator. Schumpeter's entrepreneur introduces "new combinations"-new products, production methods, markets, sources of supply, or industrial combinations_-shaking the economy out of its previous equilibrium through a process Schumpeter termed “creative destruction.” The entrepreneur-innovator is introduced in Schumpeter's ground-breaking Theory of Economic Development (1911) and

\footnotetext{
${ }^{7}$ As Gartner (1988: 21) argues, however, this literature employs a host of different (and frequently) contradictory notions of entrepreneurship. A "startling number of traits and characteristics have been attributed to the entrepreneur, and a 'psychological profile' of the entrepreneur assembled from these studies would portray someone larger than life, full of contradictions, and, conversely, someone so full of traits that (s)he would have to be a sort of generic 'Everyman."”
} 
developed further in his two-volume work, Business Cycles (1939). Realizing that the entrepreneur has no place in the general-equilibrium system of Walras, whom Schumpeter greatly admired, Schumpeter gave the entrepreneur a role as the source of economic change: ${ }^{8}$

[I]n capitalist reality as distinguished from its textbook picture, it is not [price] competition which counts but the competition from the new commodity, the new technology, the new source of supply, the new type of organization ... competition which commands a decisive cost or quality advantage and which strikes not at the margins of profits and the outputs of existing firms but at their foundations and their very lives (Schumpeter, 1942, p. 84).

While there is a substantial body of "Schumpeterian” literature, especially in technology management and evolutionary economics, the extent to which this work builds directly on Schumpeter's ideas is subject to debate. Most of the modern literature attempts to model small, continuous changes, while Schumpeter sought to explain radical, discontinuous shifts in technologies and markets. Schumpeter also paid little attention to natural selection, taking the successful innovation as the unit of analysis. As Rosenberg (p. 197) remarks, "many of Schumpeter's contributions to economic and social thought remain neglected — even by people who would not shrink from the label 'Neo-Schumpeterians.'”

Schumpeter carefully distinguished the entrepreneur from the capitalist (and strongly criticized the neoclassical economists for confusing the two). His entrepreneur need not own capital, or even work within the confines of a business firm at all. While the entrepreneur could be a manager or owner of a firm, he is more likely to be an independent contractor or craftsman. In Schumpeter’s conception, “... people act as entrepreneurs only when they actually carry out new combinations, and lose the character of entrepreneurs as soon as they have built up their business, after which they settle down to running

\footnotetext{
${ }^{8}$ This could include, but is not limited to, the formation of new business ventures.
} 
it as other people run their businesses” (Ekelund and Hébert, 1990: 569). Moreover, because Schumpeterian entrepreneurship is sui generis, independent of its environment, the nature and structure of the firm does not affect the level of entrepreneurship. Corporate $R \& D$ budgets, along with organizational structures that encourage managerial commitment to innovation (Hoskisson and Hitt, 1994), have little to do with Schumpeterian entrepreneurship per se.

This suggests a rather tenuous relationship between the entrepreneur and the firm he owns, works for, or contracts with. Entrepreneurship is exercised within the firm when it introduces new products, processes, or strategies, but not otherwise. The day-to-day operations of the firm need not involve entrepreneurship at all. Moreover, because Schumpeterian entrepreneurship is sui generis, independent of its environment, the nature and structure of the firm does not affect the level of entrepreneurship. Corporate R\&D budgets, along with organizational structures that encourage managerial commitment to innovation (Hoskisson and Hitt, 1994), have little to do with Schumpeterian entrepreneurship per se. ${ }^{9}$

\section{Entrepreneurship as Alertness}

Entrepreneurship can also be conceived as “alertness” to profit opportunities. While present in Cantillon's and J. B. Clark’s notions of entrepreneurship, this concept has been elaborated most fully by Israel Kirzner $(1973,1979,1992)$ Kirzner’s formulation emphasizes the nature of competition as a discovery process: the source of entrepreneurial profit is superior foresight - the discovery of something (new products, cost-saving technology) unknown to other market participants. The simplest case is that of the arbitrageur, who

\footnotetext{
${ }^{9}$ Other writers influenced by Schumpeter, however, such as Baumol (1993a), do view public and private R\&D, the scale and scope of patent protection, and basic science education as important determinants of the level of entrepreneurial activity.
} 
discovers a discrepancy in present prices that can be exploited for financial gain. In a more typical case, the entrepreneur is alert to a new product or a superior production process and steps in to fill this market gap before others. Success, in this view, comes not from following a well-specified maximization problem, but from having some knowledge or insight that no one else has—-that is, from something beyond the given meansend framework. ${ }^{10}$

Kirzner's entrepreneurs do not own capital; they need only be alert to profit opportunities. Because they own no assets, they bear no uncertainty. Critics have seized on this point as a defect in Kirzner's conception. According to this criticism, mere alertness to a profit opportunity is not sufficient for earning profits. To reap financial gain, the entrepreneur must invest resources to realize the discovered profit opportunity. "Entrepreneurial ideas without money are mere parlor games until the money is obtained and committed to the projects” (Rothbard, 1985: 283). Moreover, excepting the few cases where buying low and selling high are nearly instantaneous (say, electronic trading of currencies or commodity futures), even arbitrage transactions require some time to complete. The selling price may fall before the arbitrageur has made his sale, and thus even the pure arbitrageur faces some probability of loss. In Kirzner's formulation, the worst that can happen to an entrepreneur is the failure to discover an existing profit opportunity. Entrepreneurs either earn profits or break even, but it is unclear how they suffer losses.

For these reasons, the connection between Kirznerian entrepreneurship and the theory of the firm is uncertain. Owners, managers, employees, and independent contractors can

\footnotetext{
${ }^{10}$ It is important to distinguish Kirzner's view of superior foresight from Stigler's search model in which the value of new knowledge is known in advance, available to anyone willing to pay the relevant search costs. "Stigler's searcher decides how much time it is worth spending rummaging through dusty attics and untidy drawers looking for a sketch which (the family recalls) Aunt Enid thought might be by Lautrec. Kirzner's entrepreneur enters a house and glances lazily at the pictures which have been hanging in the same place for years. 'Isn't that a Lautrec on the wall?’” (Ricketts, 1987: 58).
} 
all be alert to new profit opportunities. Kirzner's entrepreneur does not need a firm to exercise his function in the economy. For these reasons, the link between Kirznerian entrepreneurship and other branches of economic analysis, such as industrial organization, innovation, and the theory of the firm, is weak. Hence Kirzner's concept has not generated a large body of applications. ${ }^{11}$

\section{Entrepreneurship as the Ability to Adjust}

Schultz (1975, 1979, 1982), like Schumpeter, works in the Walrasian tradition. However, unlike Walras and Schumpeter, Schultz recognizes that markets do not automatically and instantaneously regain equilibrium following an exogenous shock. “[R]egaining equilibrium takes time, and how people proceed over time depends on their efficiency in responding to any given disequilibrium and on the costs and returns of the sequence of adjustments available to them” (Schultz 1975, p. 829). Surprisingly, economists have devoted little attention to this problem. Even Schumpeter, who saw economic progress as the result of disruptions to existing equilibrium states, assumed that equilibrium is quickly regained following such a disruption. Schultz, by contrast, took innovation as given, and focused how economic agents adjust to exogenous shocks. An example is farmers in a developing economy. Such people must "deal with a sequence of changes in economic conditions, which are in general not of their own making because they originate mainly out of the activities of people other than farm people. For this reason Schumpeter's theory of economic development is far from sufficient to explain most of these changes” (Schultz 1975, p. 832). Moreover, the atomistic nature of agriculture and the unique aspects of farm production generate problems of collective action and by-product behavior (Olson, 1965), making such adjustments lengthier.

\footnotetext{
${ }^{11}$ Exceptions include Ekelund and Saurman (1988), Holcombe (1992), Harper (1995), and Sautet (2001).
} 
In Schultz's formulation, entrepreneurship is the ability to adjust, or reallocate one's resources, in response to changing circumstances. As such, entrepreneurship is an aspect of all human behavior, not a unique function performed by a class of specialists. "No matter what part of the economy is being investigated, we observe that people are consciously reallocating their resources in response to changes in economic conditions" (Schultz 1979:2). Businessmen, farmers, housewives, students, and even university presidents, deans, and research directors make Schultz’s (1979) list of entrepreneurs.

Somewhat paradoxically, the degree to which entrepreneurship is manifested in a society is itself determined by supply and demand. The demand for entrepreneurial services is given by the expected gains from adjusting one's resources in the face of the disequilibrium, itself a function of some characteristics of that disequilibrium. The supply of entrepreneurial capacities is given by agents' abilities to perceive and exploit opportunities. Like any economic good, entrepreneurship is valuable and scarce (Schultz 1979, p. 6). Knight and Kirzner treat entrepreneurship as "extra-economic," meaning that it is the driving force behind the pricing process, but is not itself traded and priced on the market. Schultz (1979) insists that entrepreneurial ability, like other services available for hire, is a resource with a market price and quantity, though he did not develop this insight into a fully specified theory of the supply of and demand for entrepreneurship.

Schultz conceives entrepreneurial ability as a form of human capital. Like other forms of human capital, this ability can be increased through education, training, experience, health care, and so on. While education and other human-capital investments also lead to improvements in technical and allocative efficiency, Schultz argues that efficiency improvements cannot account for all of the effects of education on economic performance, particularly in agricultural communities during periods of modernization. At 
least part of the returns to education are the returns to improved abilities to adjust to change, for instance by adopting new technology and organizational practices. Moreover, an economy’s aggregate stock of entrepreneurial ability can also be increased by the immigration of people with particular entrepreneurial experiences and skills (presumably in response to increased opportunities for entrepreneurial gain).

\section{Entrepreneurship as Charismatic Leadership}

Another strand of literature, incorporating insights from economics, psychology, and sociology and leaning heavily on Max Weber, associates entrepreneurship with charismatic leadership. Entrepreneurs, in this view, specialize in communication — the ability to articulate a plan, a set of rules, or a broader vision, and impose it on others. Casson (2000) calls these plans "mental models" of reality. The successful entrepreneur excels at communicating these models to others, who come to share the entrepreneur's vision (and become his followers). Such entrepreneurs are also typically optimistic, self-confident, and enthusiastic (though it is not clear whether these are necessary conditions).

Witt (1998a, 1998b) describes entrepreneurship similarly as “cognitive leadership.” He outlines an entrepreneurial theory of the firm that combines recent literature on cognitive psychology with Kirzner's concept of alertness. Entrepreneurs require complementary factors of production, he argues, which are coordinated within the firm. For the firm to be successful, the entrepreneur must establish a tacit, shared framework of goals, which governs the relationships among members of the entrepreneur's team. As Langlois (1998) points out, it is often easier (less costly) for individuals to commit to a specific individual, the leader, rather than an abstract set of complex rules governing the firm's 
operations. The appropriate exercise of charismatic authority, then, reduces coordination costs within organizations.

A possible weakness of this approach, in our view, is its emphasis on human assets, rather than the inalienable physical assets the entrepreneur controls. Must the charismatic leader necessarily own physical capital, or can he be an employee or independent contractor? Formulating a business plan, communicating a "corporate culture," and the like are clearly important dimensions of business leadership. But are they attributes of the successful manager or the successful entrepreneur? Even if top-level managerial skill were the same as entrepreneurship, it is unclear why charismatic leadership should be regarded as more "entrepreneurial” than other, comparatively mundane managerial tasks such as structuring incentives, limiting opportunism, administering rewards, and so on.

\section{Entrepreneurship as Judgment}

An alternative to the foregoing accounts is that entrepreneurship consists of judgmental decision-making under conditions of uncertainty. Judgment refers primarily to business decision-making when the range of possible future outcomes, let alone the likelihood of individual outcomes, is generally unknown (what Knight [1921] terms uncertainty, rather than mere probabilistic risk). This view finds expression in the earliest known discussion of entrepreneurship, that found in Richard Cantillon's Essai sur la nature de commerce en géneral (1755). Cantillon argues that all market participants, with the exception of landowners and the nobility, can be classified as either entrepreneurs or wage earners:

Entrepreneurs work for uncertain wages, so to speak, and all others for certain wages until they have them, although their functions and their rank are very disproportionate. The General who has a salary, the Courtier who has a pension, and the Domestic who has wages, are in the latter class. All 
the others are Entrepreneurs, whether they establish themselves with a capital to carry on their enterprise, or are Entrepreneurs of their own work without any capital, and they may be considered as living subject to uncertainty; even Beggars and Robbers are Entrepreneurs of this class (Cantillon, 1755: 54).

Bearing risk — that is, making decisions under conditions of uncertainty—is the entrepreneur's raison d'être.

Judgment is distinct from boldness, innovation, alertness, and leadership. Judgment must be exercised in mundane circumstances, for ongoing operations as well as new ventures. While alertness tends to be passive (perhaps even hard to distinguish from luck, Demsetz 1983), judgment is active. Alertness is the ability to react to existing opportunities while judgment refers to the creation of new opportunities. ${ }^{12}$ Entrepreneurs "are those who seek to profit by actively promoting adjustment to change. They are not content to passively adjust their . . activities to readily foreseeable changes or changes that have already occurred in their circumstances; rather, they regard change itself as an opportunity to meliorate their own conditions and aggressively attempt to anticipate and exploit it” (Salerno, 1993: 123). Those who specialize in judgmental decision-making may be dynamic, charismatic leaders, but they need not possess these traits. Decision making under uncertainty is entrepreneurial, whether it involves imagination, creativity, leadership, and related factors or not. ${ }^{13}$

\footnotetext{
${ }^{12}$ In Kirzner's treatment, entrepreneurship is characterized as "a responding agency. I view the entrepreneur not as a source of innovative ideas ex nihilo, but as being alert to the opportunities that exist already and are waiting to be noticed" (Kirzner, 1973, p. 74).

${ }^{13}$ In Mises's (1949) formulation, entrepreneurship is introduced to explain the existence of profit and loss. In the marginal productivity theory of distribution, laborers earn wages, capitalists earn interest, and owners of specific factors earn rents. Any excess (deficit) of a firm's realized receipts over these factor payments constitutes profit (loss). Profit and loss, therefore, are returns to entrepreneurship. In a hypothetical equilibrium without uncertainty (what Mises calls the "evenly rotating economy"), capitalists would still earn interest, as a reward for lending, but there would be no profit or loss.
} 
Knight introduces judgment to link profit and the firm to uncertainty. Entrepreneurship represents judgment that cannot be assessed in terms of its marginal product and which cannot, accordingly, be paid a wage (Knight, 1921: p. 311). In other words, there is no market for the judgment that entrepreneurs rely on, and therefore exercising judgment requires the person with judgment to start a firm. Judgment thus implies asset ownership, for judgmental decision making is ultimately decision making about the employment of resources. An entrepreneur without capital goods is, in Knight's sense, no entrepreneur (Foss and Klein, 2005).

Entrepreneurship as uncertainty bearing is also important for Mises's theory of profit and loss, a cornerstone of his well-known critique of economic planning under socialism. Mises begins with the marginal productivity theory of distribution developed by his Austrian predecessors. In the marginal productivity theory, laborers earn wages, capitalists earn interest, and owners of specific factors earn rents. Any excess (deficit) of a firm's realized receipts over these factor payments constitutes profit (loss). Profit and loss, therefore, are returns to entrepreneurship. In a hypothetical equilibrium without uncertainty (what Mises calls the "evenly rotating economy”), capitalists would still earn interest, as a reward for lending, but there would be no profit or loss.

Entrepreneurs, in Mises's understanding of the market, make their production plans based on the current prices of factors of production and the anticipated future prices of consumer goods. What Mises calls "economic calculation" is the comparison of these anticipated future receipts with present outlays, all expressed in common monetary units. Under socialism, the absence of factor markets, and the consequent lack of factor prices, renders economic calculation—and hence rational economic planning-impossible. Mises's point is that a socialist economy may employ workers, managers, technicians, 
inventors, and the like, but it cannot, by definition, employ entrepreneurs, because there are no money profits and losses. Entrepreneurship, and not labor or management or technological expertise, is the crucial element of the market economy. As Mises puts it: managers of socialist enterprises may be allowed to "play market," to act as if they were managers of private firms with their own interests at stake, but entrepreneurs cannot be asked to “play speculation and investment” (Mises, 1949, p. 705). Absent entrepreneurship a complex, dynamic economy cannot allocate resources to their highest valued use. ${ }^{14}$

\section{Entrepreneurial Judgment as a Natural Complement to the Theory of the Firm}

While the view of entrepreneurship as judgment appears in many writers, it is most often associated with Knight (1921). For Knight, firm organization, profit, and the entrepreneur are closely related. In his view, these arise as an embodiment, a result, and a cause, respectively, of commercial experimentation (Demsetz, 1988). ${ }^{15}$

Knight introduces the notion of judgment to link profit and the firm to the existence of uncertainty. Judgment primarily refers to the process of businessmen forming estimates of future events in situations in which there is no agreement or idea at all on probabilities of occurrence. It may be defined as a service that enhances the quality of decisions in novel situations that require an urgent decision, a service that is learned and has a large tacit com-

\footnotetext{
${ }^{14}$ Mises and Kirzner are usually treated together as offering a unified Austrian account of the entrepreneur. Indeed, Kirzner, a leading member of the modern Austrian school, received his Ph.D. under Mises at New York University and has described his work as the working out of various parts of Mises's system. However, we see Mises in the Cantillon-Knight tradition of viewing entrepreneurship as judgment over the deployment of resources, not alertness per se. Kirzner (1973: 39-40) agrees that in a world of uncertainty, resource owners exercise entrepreneurial judgment in allocating their resources to particular uses. But he goes on (1973: 40-43) to introduce the analytical device of "pure entrepreneurship," the act of discovery or alertness to profit opportunities by those with no resources under their control, and claims that this function, rather than uncertainty-bearing, is the "driving force" behind the market economy. We do not find the concept of pure entrepreneurship or the "alertness" metaphor useful to understanding the nature of the market system. For more on this see Klein (1999: 24-25).

${ }^{15}$ Knight explains that "[w]ith uncertainty entirely absent, every individual being in possession of perfect knowledge, there would be no occasion for anything of the nature of responsible management or control of productive activities ... Its existence in the world is a direct result of the fact of uncertainty" $(1921: 267,271)$.
} 
ponent. Entrepreneurship represents judgment that cannot be assessed in terms of its marginal product and which cannot, accordingly, be paid a wage. ${ }^{16}$ This is because entrepreneurship is judgment in relation to the most uncertain events, such as starting a new firm, defining a new market, and the like.

In other words, there is no market for the judgment that entrepreneurs rely on, and utilizing judgment therefore requires the person with judgment to start a firm. Moreover, judgment implies asset ownership. Judgmental decision-making is ultimately decisionmaking about the employment of resources. An entrepreneur without capital goods is, in Knight's sense, no entrepreneur. ${ }^{17}$ This implies an obvious link with the theory of the firm, particularly those (transaction cost and property rights theories) that define asset ownership as a crucial ingredient of firm organization (Williamson, 1996; Hart, 1995). The firm, in this sense, is the entrepreneur and the assets he owns, and therefore ultimately controls. The theory of the firm is essentially a theory of how the entrepreneur exercises his judgmental decision-making — what combinations of assets will he seek to acquire, what (proximate) decisions will he delegate to subordinates, how will he provide incentives and employ monitoring to see that his assets are used consistently with his judgments, and so on.

\footnotetext{
16 "The receipt of profit in a particular case may be argued to be the result of superior judgment. But it is judgment of judgment, especially one's own judgment, and in an individual case there is no way of telling good judgment from good luck and a succession of cases sufficient to evaluate the judgment or determine its probable value transforms the profit into a wage. . . . If . . . capacities were known, the compensation for exercising them can be competitively imputed and is a wage; only, in so far as they are unknown or known only to the possessor himself, do they give rise to a profit” (Knight, 1921: 311).

${ }^{17}$ Carl Menger's (1871) treatment of production gives the entrepreneur a similar role. Production requires an "act of will" and "supervision of the execution of the production plan." These functions "entail property ownership and, therefore, mark the Mengerian entrepreneur as a capitalist-entrepreneur" (Salerno, 1998: 30). Menger describes "command of the services of capital" as a "necessary prerequisite" for economic activity. Even in large firms, although he may employ "several helpers," the entrepreneur himself continues to bear uncertainty, perform economic calculation, and supervise production, even if these functions "are ultimately confined ... to determining the allocation of portions of wealth to particular productive purposes only by general categories, and to selection and control of persons” (Menger, 1871: 160-61).
} 


\section{ENTREPRENEURSHIP, OPPORTUNITY IDENTIFICATION, AND OPPORTUNITY EXPLOITATION}

As noted above, while Schumpeter, Kirzner, Cantillon, Knight, and Mises are frequently cited in the contemporary entrepreneurship literature in economics and management (Schultz, by contrast, is rarely cited), much of this literature takes, implicitly, an occupational or structural approach to entrepreneurship. Any relationship to the classic functional contributions is inspirational, not substantive.

The most important exception is the rapidly growing literature in management and organization theory on opportunity discovery or opportunity identification, or what Shane (2003) calls the “individual-opportunity nexus.” Opportunity identification involves not only technical skills like financial analysis and market research, but also less tangible forms of creativity, team building, problem solving, and leadership (Long and McMullan, 1984; Hills, Lumpkin, and Singh, 1997; Hindle, 2004). It can involve both the recognition of already existing opportunities and the creation, ex nihilo, of new opportunities (Alvarez and Barney, 2007). While value can of course be created not only by starting new activities, but also by improving the operation of existing activities, research in opportunity identification tends to emphasize the launching of new ventures (firms, products, or services). As summarized by Shane (2003: 4-5):

Entrepreneurship is an activity that involves the discovery, evaluation, and exploitation of opportunities to introduce new goods and services, ways of organizing, markets, process, and raw materials through organizing efforts that previously had not existed (Venkataraman, 1997; Shane and Venkataraman, 2000). Given this definition, the academic field of entrepreneurship incorporates, in its domain, explanations for why, when and how entrepreneurial opportunities exist; the sources of those opportunities and the forms that they take; the processes of opportunity discovery and evaluation; the acquisition of resources for the exploitation of these opportunities; the act of opportunity exploitation; why, when, and how some individuals and not others discover, evaluate, gather resources for and ex- 
ploit opportunities; the strategies used to pursue opportunities; and the organizing efforts to exploit them (Shane and Venkataraman, 2000).

This conception makes opportunities, and their discovery and (potential) exploitation, the unit of analysis for entrepreneurship research. A precise definition of opportunities, however, has been elusive.

\section{Opportunities: Objective or Subjective?}

Shane and Venkataraman (2000, p. 220) define entrepreneurial opportunities as "those situations in which new goods, services, raw materials, and organizing methods can be introduced and sold at greater than their cost of production.” These opportunities are treated as objective phenomena, though their existence is not known to all agents. Shane and Venkataraman also distinguish entrepreneurial opportunities from profit opportunities more generally. While the latter reflect opportunities to create value by enhancing the efficiency of producing existing goods, services, and processes, the former refer to value creation through "the discovery of new means-ends frameworks." Shane and Venkataraman seem to have in mind the distinction between activities that can be modeled as solutions to well-specified optimization problems—what Kirzner (1973) calls “Robbinsian maximizing”- and those for which no existing model, or decision rule, is available.

However, Shane and Venkataraman appear to misunderstand Kirzner (and the Austrians more generally) on this point. In a world of Knightian uncertainty, all profit opportunities involve decisions for which no well-specified maximization problem is available. Kirzner does not mean that some economic decisions really are the result of Robbinsian maximizing while others reflect discovery. Instead, Kirzner is simply contrasting two 
methodological constructions for the analysis of human action. In Knightian terms, profit is never the result of bearing risk, but always the result of bearing uncertainty.

Not recognizing that Kirzner's discovery metaphor is an instrumental construct, the opportunity identification literature seeks to build a positive research program by operationalizing the concept of alertness. As summarized by Gaglio and Katz (2001):

Almost all of the initial empirical investigations of alertness have focused on the means by which an individual might literally "notice without search.” For example, Kaish and Gilad (1991) interpret this as having an aptitude to position oneself in the flow of information so that the probability of encountering opportunities without a deliberate search for a specific opportunity is maximized. Therefore, in their operational measures of alertness, they asked founders to recall: (a) the amount of time and effort exerted in generating an information flow; (b) the selection of information sources for generating an information flow; and (c) the cues inherent in information that signal the presence of an opportunity. From this data the authors deduced: (d) the quantity of information in the flow and (e) the breadth and diversity of information in the flow.

Their results conform to expectations in some ways but also reveal some unexpected patterns. Compared to the sample of corporate executives, the sample of new venture founders do appear to spend more time generating an information flow and do seem more likely to use unconventional sources of information. Interestingly, the founders do seem more attentive to risk cues rather than to market potential cues. However, the data also reveal that only inexperienced or unsuccessful founders engage in such intense information collection efforts. Successful founders actually behave more like the sample of corporate executives. Cooper et al. (1995) found a similar pattern of results in their survey of 1100 firms although Busenitz (1996), in an altered replication of Kaish and Gilad's survey, did not. Indeed Busenitz found few significant differences between corporate managers and new venture founders. In addition, validity checks of the survey measures yielded low reliability scores, which led the author to conclude that future research in alertness required improved theoretical and operational precision.

To an Austrian economist, however, this positive research program misses the point of Kirzner's metaphor of entrepreneurial alertness: namely, that it is only a metaphor. Kirzner's aim is not to characterize entrepreneurship per se, but to explain the tendency for markets to clear. In the Kirznerian system opportunities are (exogenous) arbitrage 
opportunities and nothing more. Entrepreneurship itself serves a purely instrumental function; it is the means by which Kirzner explains market clearing. For this reason, Kirzner offers no theory of how opportunities come to be identified, who identifies them, and so on; identification itself is a black box. The claim is simply that outside the ArrowDebreu world in which all knowledge is effectively parameterized, opportunities for disequilibrium profit exist and tend to be discovered and exploited. In short, what Kirzner calls "entrepreneurial discovery" is simply that which causes markets to equilibrate.

Contemporary entrepreneurship scholars, considering whether opportunities are objective or subjective (McMullen and Shepherd, 2006; Companys and McMullen, 2007), note that Kirzner tends to treat them as objective. Again, this is true, but misses the point. Kirzner is not making an ontological claim about the nature of profit opportunities per se-not claiming, in other words, that opportunities are, in some fundamental sense, objective-but merely using the concept of objective, exogenously given, but not-yetdiscovered opportunities as a device for explaining the tendency of markets to clear.

The Knightian perspective also treats entrepreneurship as an instrumental construct, used here to decompose business income into two constituent elements, interest and profit. Interest is a reward for forgoing present consumption, is determined by the relative time preferences of borrowers and lenders, and would exist even in a world of certainty. Profit, by contrast, is a reward for correctly anticipating the uncertain future (e.g., purchasing factors of production at prices below the eventual selling price of the product), and exists only in a world of "true" uncertainty. In such a world, given that production takes time, entrepreneurs will earn either profits or losses based on the differences between factor prices paid and product prices received. 
For Knight, in other words, opportunities do not exist, waiting to be discovered (and hence, by definition, exploited). Rather, entrepreneurs invest resources based on their expectations of future consumer demands and market conditions, investments that may or may not yield positive return. Here the focus is not on opportunities, but on investment and uncertainty. Expectations about the future are inherently subjective and, under conditions of uncertainty rather than risk, constitute judgments that are not themselves modelable. Put differently, subjectivism implies that opportunities are neither "discovered” nor “created” (Alvarez and Barney, 2007), but perceived. They may or may not exist, in an objective sense. Hence a research program based on formalizing and studying empirically the processes leading individuals to discover opportunities, whether based on economics or psychology, are misguided. Opportunities for entrepreneurial gain are thus inherently subjective, in the sense that they do not exist until profits are realized.

\section{Opportunities as a Black Box}

Confusion over the nature of opportunities is increasingly recognized. As noted by McMullen, Plummer, and Acs (2007: 273),

a good portion of the research to date has focused on the discovery, exploitation, and consequences thereof without much attention to the nature and source of opportunity itself. Although some researchers argue that the subjective or socially constructed nature of opportunity makes it impossible to separate opportunity from the individual, others contend that opportunity is as an objective construct visible to or created by the knowledgeable or attuned entrepreneur. Either way, a set of weakly held assumptions about the nature and sources of opportunity appear to dominate much of the discussion in the literature.

Do we need a precise definition of opportunities to move forward? Can one do entrepreneurship research without specifying what, exactly, entrepreneurial opportunities “are”? Can we treat opportunities as a "black box,” much as other concepts in manage- 
ment such as culture, leadership, routines, capabilities, and the like are treated (Abell, Felin, and Foss, 2007)?

One approach is to focus not on what opportunities are, but what opportunities do. Opportunities, in this sense, are treated as a latent construct that is manifested in entrepreneurial action—investment, creating new organizations, bringing products to market, and so on. A direct analogy can be drawn to the economist's notion of preferences. Economic theory (with the exception of behavioral economics, discussed below) takes agents’ preferences as given and derives implications for choice. The economist does not care what preferences "are,” ontologically, but simply postulates their existence and draws inferences about their characteristics as needed to explain particular kinds of economic behavior. Empirically, this approach can be operationalized by treating entrepreneurship as a latent variable in a structural-equations framework (Xue and Klein, 2007).

By treating opportunities as a latent construct, this approach sidesteps the problem of defining opportunities as objective or subjective, real or imagined, and so on. The formation of entrepreneurial beliefs is treated as a potentially interesting psychological problem, but not part of the economic analysis of entrepreneurship. It also avoids thorny questions about whether alertness or judgment is simply luck (Demsetz, 1983), a kind of intuition (Dane and Pratt, 2007), or something else entirely.

\section{The Unit of Analysis}

If opportunities are inherently subjective, and we treat them as a black box, then the unit of analysis should not be opportunities, but rather some action-in Knightian terms, the assembly of resources in the present in anticipation of (uncertain) receipts in the future. Again, the analogy with preferences in microeconomic theory is clear: the unit of 
analysis in consumer theory is not preferences but consumption. In neoclassical production theory the unit of analysis is not the production function but some decision variable.

One way to capture the Knightian concept of entrepreneurial action is Casson's notion of "projects" (Casson, 2007; Casson and Wadeson, 2007). A project is a stock of resources committed to particular activities for a specified period of time. (Opportunities are defined as potential, but currently inactive, projects). Focusing on projects, rather than opportunities, implies an emphasis not on opportunity identification, but on opportunity exploitation, not identification. More generally, this perspective suggests that entrepreneurship research should focus on the execution of business plans. ${ }^{18}$

\section{CONCLUSIONS}

This brief review of the entrepreneurship literature reveals a tremendous variety in how economists and management theorists have conceived the entrepreneurial function, along with how they have modeled the occupation of self-employment and the choice of firms to invest and grow. Our analysis suggests that the over-reliance on the origins and characteristics of entrepreneurial opportunities may have hampered the integration of entrepreneurship into economics and strategic management. Instead of focusing on opportunities per se, researchers might do better by treating opportunities as a latent construct that is manifested in entrepreneurial action, namely the exercise of judgment over the arrangement of heterogeneous capital assets. The Austrian theory of capital, interpreted in the "attributes" framework described above, provides a useful framework for conducting such analysis, linking the Knightian theory of entrepreneurship and the theory of economic organization. In short, we suggest a re-orientation of the entrepreneurship litera-

\footnotetext{
${ }^{18}$ See Salerno (2007) for the case that the Austrian economists, prior to Kirzner (1973), uniformly emphasized property ownership as inextricably linked to entrepreneurship.
} 
ture toward deeds, not words or dreams. In Rothbard’s (1985, p. 283) words: "Entrepreneurial ideas without money are mere parlor games until the money is obtained and committed to the projects." Of course, the subjectivist, Austrian concept of resources is inextricably tied to beliefs—vision, imagination, new mental models, if you like—but these beliefs are relevant only to the extent that they are manifest in action.

One objection to this approach is to invoke recent literature in behavioral economics and neuro-economics. This literature takes preferences, not choices, as its unit of analysis, seeking to understand the psychological basis of preference, the consistency of preferences, and the like, rather than taking preferences as an irreducible primary. Likewise, a theory of opportunity identification could mimic the methods of behavioral economics and neuro-economics. This is indeed a potentially fruitful avenue for entrepreneurship research. However, like behavioral economics, such an approach has more in common with applied psychology than economics per se. It may contribute to a general, interdisciplinary approach to entrepreneurship, but is not an integral part of the economic theory of entrepreneurship. 


\section{REFERENCES}

Abell, Peter, Teppo Felin, and Nicolai J. Foss. 2007. "Building Microfoundations for the Routines, Capabilities, and Performance Links.” Managerial and Decision Economics, forthcoming.

Acs, Zoltan, and David B. Audretsch. 1990. Innovation and Small Firms. Cambridge, Mass.: MIT Press.

Aghion, Philippe and Peter Howitt. 1992. “A Model of Growth through Creative Destruction.” Econometrica 60(2), 323-351.

Aldrich, Howard E. 1990. "Using an Ecological Perspective to Study Organizational Founding Rates.” Entrepreneurship Theory and Practice 14(3): 7-24.

Aldrich, Howard E. and Gabriele Wiedenmayer. 1993. "From Traits to Rates: An Ecological Perspective on Organizational Foundings," in Jerome Katz and Robert Brockhaus, eds., Advances in Entrepreneurship, Firm Emergence, and Growth. Greenwich, Conn.: JAI Press, pp. 145-195.

Alvarez, Sharon A., and Jay B. Barney. 2007. "Discovery and Creation: Alternative Theories of Entrepreneurial Action.” Journal of Management Studies, forthcoming.

Audretsch, David B., Max Keilbach, and Erik Lehmann. 2005. Entrepreneurship and Economic Growth. Oxford: Oxford University Press.

Barney, J. B. 1991. "Firm Resources and Sustained Competitive Advantage”, Journal of Management 17: 99-120.

Baumol, W. 1993. Entrepreneurship, Management, and the Structure of Payoffs. Cambridge, MA: MIT Press.

Begley, Thomas and David Boyd. 1987. "Psychological Characteristics Associated with Performance in Entrepreneurial Firms and Smaller Businesses," Journal of Business Venturing 2: 79-93.

Bianchi, M. and M. Henrekson. 2005. "Is Neoclassical Economics Still Entrepreneurless?," Kyklos 58: 353-377.

Busenitz, L. W. 1996. "Research on Entrepreneurial Alertness,” Journal of Small Business Management, 34: 35-44.

Cantillon, Richard. 1755. Essai sur la nature de commerce en géneral. Henry Higgs, ed. London: Macmillan, 1931.

Casson, M. C. 1982/1999. The Entrepreneur: An Economic Theory. Oxford: Martin Robertson, 2nd. ed. Edward Elgar.

Casson, Mark C. 2000. "An Entrepreneurial Theory of the Firm,” in Nicolai J. Foss and Volker Mahn, eds. Competence, Governance and Entrepreneurship: Advances in Economic Strategy Research, New York: Oxford University Press.

Casson, Mark C. 2007. "The Economic Theory of Entrepreneurship: A Systems View.” Journal of Management Studies, forthcoming.

Casson, Mark C., and Nigel Wadeson. 2007. "The Discovery of Opportunities: Extending the Economic Theory of the Entrepreneur.” Small Business Economics 28(4): 285-300. 
Chandler, G. N. and E. E. Jansen. 1992. “The Founder's Self-Assessed Competence and Venture Performance,“ Journal of Business Venturing 7: 223-236

Companys, Yosem, and Jeffery McMullen. 2007. "Strategic Entrepreneurs at Work: The Nature, Discovery, and Exploitation of Entrepreneurial Opportunities.” Small Business Economics 28(4): 301-22.

Cooper, A. C., T. B. Folta and C. Woo. 1995. "Entrepreneurial Information Search," Journal of Business Venturing 10: 107-20.

Dane, Erik, and Michael Pratt. 2007. "Exploring Intuition and Its Role In Managerial Decision Making.” Academy of Management Review 32(1): 33-54.

Demsetz, Harold. 1983. “The Neglect of the Entrepreneur.” In Joshua Ronen, ed. Entrepreneurship. Lexington: Lexington Press.

Demsetz, Harold. 1988. "Profit as a Functional Return: Reconsidering Knight's Views," in idem. 1988. Ownership, Control and the Firm. Oxford and New York: Blackwell.

Demsetz, Harold. 1991. "The Theory of the Firm Revisited," in Oliver E. Williamson and Sidney G. Winter, eds. 1991. The Nature of the Firm, Oxford: Blackwell.

Ekelund, Robert B., Jr., and David S. Saurman. 1988. Advertising and the Market Process: A Modern Economic View. San Francisco: Pacific Research Institute.

Ekelund, Robert B., Jr., and Robert F. Hébert. 1990. A History of Economic Thought and Method. Third edition. New York: McGraw-Hill.

Elkjaer, Jørgen R. 1991. "The Entrepreneur in Economic Theory: An Example of the Development and Influence of a Concept,” History of European Ideas 13: 805-15.

Finkle T. A., and D. Deeds. 2001. "Trends in the Market for Entrepreneurship Faculty, 1989-1998.” Journal of Business Venturing 16: 613-30.

Foss, Nicolai J. 2000. “Equilibrium versus Evolution: The Conflicting Legacies of Demsetz and Penrose," in Nicolai J. Foss and Paul Robertson. Resources, Technology, and Strategy: Explorations in the Resource-based View. London: Routledge.

Foss, Nicolai J. and Peter G. Klein. 2002. Entrepreneurship and the Theory of the Firm. Aldershot: Edward Elgar.

Foss, Nicolai J. 2003. "Selective Intervention and Internal Hybrids: Interpreting and Learning from the Rise and Decline of the Oticon Spaghetti Organization," Organization Science, 3: 331-349.

Foss, Nicolai J., and Peter G. Klein. 2005.."Entrepreneurship and the Economic Theory of the Firm: Any Gains from Trade?” In Rashjree Agarwal, Sharon A. Alvarez, and Olaf Sorenson, eds., Handbook of Entrepreneurship Research: Disciplinary Perspectives. Dordrecht: Springer.

Foss, Nicolai J., Peter G. Klein, Yasemin Y. Kor, and Joseph T. Mahoney. 2008. “Entrepreneurship, Subjectivism, and the Resource-Based View: Towards a New Synthesis.” Working Paper, College of Business Administration, University of Illinois Urbana-Champaign. 
Gaglio, C. M. and J. A. Katz. 2001. "The Psychological Basis of Opportunity Identification: Entrepreneurial Alertness,” Small Business Economics 16: 95-111.

Gartner, W. B. 1988. "Who is An Entrepreneur? Is the Wrong Question," American Journal of Small Business 12: 11-32.

Gartner, W. B., and K. H. Vesper. 1999. University Entrepreneurship Programs. Los Angeles: Lloyd Grief Center for Entrepreneurial Studies, University of Southern California.

Harper, David. 1995. Entrepreneurship and the Market Process: An Inquiry into the Growth of Knowledge. London: Routledge.

Hart, Oliver. 1995. Firms, Contracts and Financial Structure. Oxford: Clarendon Press.

Hayek, F. A. 1931. "Richard Cantillon.” In The Collected Works of F. A. Hayek, volume 3: The Trend of Economic Thinking, ed. W. W. Bartley III and Stephen Kresge. Chicago: University of Chicago Press, pp. 245-94.

Hindle, K. 2004. "Choosing Qualitative Methods for Entrepreneurial Cognition Research: A Canonical Development Approach,” Entrepreneurship Theory and Practice 28(6): 575-607.

Hills, G.E., G.T. Lumpkin, and R.P. Singh. 1997. "Opportunity Recognition: Perceptions and Behaviors of Entrepreneurs," Frontiers of Entrepreneurship Research 17: 16882.

Holcombe, Randall G. 1992. "Political Entrepreneurship and the Democratic Allocation of Economic Re-sources,” Review of Austrian Economics 15: 143-59.

Holmes, Thomas J. and James A. Schmitz. 2001. "A Gain from Trade: From Unproductive to Productive Entrepreneurship,” Journal of Monetary Economics 47(2): 417446.

Hood, Jacqueline N. and John E. Young. 1993. "Entrepreneurship’s Requisite Areas of Development: A Survey of Top Executives in Successful Entrepreneurial Firms," Journal of Business Venturing 8(2): 115-135.

Hoskisson, Robert E., and Michael A. Hitt. 1994. Downscoping: How to Tame the Diversified Firm.. New York: Oxford University Press.

Ibrahim, G. and S. Vyakarnam. 2003. "Defining the Role of the Entrepreneur in Economic Thought: Limitations of Mainstream Economics," Working Paper, Nottingham Business School.

Kaish, S. and B. Gilard. 1991. "Characteristics of Opportunities Search of Entrepreneurs Versus Executives: Sources, Interests, General Alertness,” Journal of Business Venturing 6: 54-61.

Katz, J. A. 2003. "The Chronology and Intellectual Trajectory of American Entrepreneurship Education.” Journal of Business Venturing 18: 283-300.

Kihlstrom, Richard E. and Jean-Jacques Laffont. 1979. “A General Equilibrium Entrepreneurial Theory of Firm Formation Based on Risk Aversion.” Journal of Political Economy 87, no. 4: 719-48. 
Kirzner, Israel M. 1973. Competition and Entrepreneurship. Chicago: University of Chicago Press.

Kirzner, Israel M. 1979. Perception, Opportunity and Profit: Studies in the Theory of Entrepreneurship. Chicago: University of Chicago Press.

Kirzner, Israel M. 1985. “The Perils of Regulation,“ in idem., Discovery and the Capitalist Process. Chicago: University of Chicago Press, 1985.

Kirzner, Israel M. 1992. The Meaning of Market Process. London: Routledge.

Knight, Frank H. 1921. Risk, Uncertainty, and Profit. New York: August M. Kelley.

Kuratko, D. F. 2003. "Entrepreneurship Education: Emerging Trends and Challenges for the 21st Century.” White Paper, U.S. Association of Small Business Education.

Langlois, Richard N., and Metin Cosgel. 1993. "Frank Knight on Risk, Uncertainty, and the Firm: A New Interpretation.” Economic Inquiry 31: 456-65.

Langlois, Richard N. 1998. "Personal Capitalism as Charismatic Authority: The Organizational Economics of a Weberian Concept," Industrial and Corporate Change 7: 195-213.

Langlois, Richard N. and Nicolai J. Foss. 1999. "Capabilities and Governance: the Rebirth of Production in the Theory of Economic Organization,” KYKLOS 52: 201-218.

Lazear, Edward P. 2004. "Balanced Skills and Entrepreneurship," The American Economic Review 94(2): 208-211.

Lippman, Steven A. and Richard P. Rumelt. 1982.”Uncertain Imitability: An Analysis of Interfirm Differences in Efficiency under Competition,” The Bell Journal of Economics 13(2): 418-438.

Long, W. A. and McMullan, W. E. 1984. "Entrepreneurship education in the nineties," Journal of Business Venturing 2(3): 261-275.

Lumpkin, G. T. and Gregory G. Dess. 1996. "Clarifying the Entrepreneurial Orientation Construct and Linking It to Performance," The Academy of Management Review 21(1): 135-172.

Machovec, Frank M. 1995. Perfect Competition and the Transformation of Economics. New York: Routledge.

Matthews, J. 2006. Strategizing, Disequilibrium, and Profit. Stanford: Stanford University Press.

McGrath, Rita G. and Ian C. MacMillan. 2000. The Entrepreneurial Mindset: Strategies for Continuously Creating Opportunity in an Age of Uncertainty. U.S., Boston: Harvard Business School Press.

McMullen, Jeffery, Lawrence Plummer, and Zoltan Acs. 2007. "What is an Entrepreneurial Opportunity?” Small Business Economics 28(4): 273-83.

McMullen, Jeffrey, and Dean A. Shepherd. 2006. "Entrepreneurial Action and the Role of Uncertainty in the Theory of the Entrepreneur." Academy of Management Review 31(1): 132-52. 
McNulty, Paul. 1984. "On the Nature and Theory of Economic Organization: The Role of the Firm Reconsidered," History of Political Economy 16: 223-53.

Menger, Carl. 1871. Principles of Economics. New York: New York University Press, 1985.

Mises, Ludwig von. 1949. Human Action: A Treatise on Economics. New Haven: Yale University Press.

O'Brien, Dennis. 1984. "The Evolution of the Theory of the Firm," in idem., Methodology, Money and the Theory of the Firm, Vol. 1. Aldershott, UK.: Edward Elgar, 1994.

O’Brien, Dennis. 1990. "Marshall’s Industrial Analysis,” Scottish Journal of Political Economy 37: 61-84.

Olson, Mancur. 1965. The Logic of Collective Action: Public Goods and the Theory of Groups. Cambridge, Mass.: Harvard University Press.

Parker, Simon C. 2004. The Economics of Self-employment and Entrepreneurship. Cambridge: Cambridge University Press.

Penrose, E. T. 1959. The Theory of the Growth of the Firm. Oxford: Oxford University Press.

Peteraf, M. A. 1993. "The Cornerstones of Competitive Advantage: A Resource-Based view”, Strategic Management Journal 14: 179-191.

Ricketts, Martin. 1987. The New Industrial Economics: An Introduction to Modern Theories of the Firm. New York: St. Martin's Press.

Rothbard, Murray N. 1985. "Professor Hébert on Entrepreneurship.” In Rothbard, The Logic of Action Two: Applications and Criticism from the Austrian School. Aldershott, U.K.: Edward Elgar 1997, pp. 245-53.

Rothbard, Murray N. 1995. An Austrian Perspective on the History of Economic Thought, volume 1: Economic Thought Before Adam Smith. Cheltenham, U.K.: Edward Elgar.

Salerno, Joseph T. 1993. "Mises and Hayek Dehomogenized," Review of Austrian Economics 6: 113-46.

Salerno, Joseph T. 1998. "The Rebirth of Austrian Economics-In Light of Austrian Economics,” Quarterly Journal of Austrian Economics 1(2): 1-28.

Salerno, Joseph T. 2007. “The Entrepreneur: Real and Imagined.” Working Paper, Ludwig von Mises Institute.

Sautet, Frederic. 2001. An Entrepreneurial Theory of the Firm. London: Routledge.

Schultz, T.W. 1975. “The Value of the Ability to Deal with Disequilibria.” Journal of Economic Literature 13: 827-46.

Schultz, T.W. 1979. “Concepts of Entrepreneurship and Agricultural Research,” Kaldor Memorial Lecture, Iowa State University, October.

Schultz, T.W. 1982. "Investment in Entrepreneurial Ability.” Scandinavian Journal of Economics 82: 437-48. 
Schumpeter, Joseph A. 1911. The Theory of Economic Development: An Inquiry into Profits, Capital, Credit, Interest, and the Business Cycle. Cambridge, Mass.: Harvard University Press, 1934.

Schumpeter, Joseph A. 1939. Business Cycles: A Theoretical, Historical and Statistical Analysis of the Capitalist Process. New York: McGraw-Hill.

Schumpeter, Joseph A. 1942. Capitalism, Socialism, and Democracy. New York: Harper \& Row.

Shane, S. 2003. A General Theory of Entrepreneurship. Cheltenham: Edward Elgar.

Shane, S. and S. Venkataraman. 2000. "The Promise of Entrepreneurship as a Field of Research,” Academy of Management Review 25:217-226.

Shaver, Kelly G., and Linda R. Scott. 1991. "Person, Process, Choice: The Psychology of New Venture Creation.” Entrepreneurship Theory and Practice 16: 23-45.

Solomon, G.T., S. Duffy, and A. Tarabishy. 2002. "The State of Entrepreneurship Education in the United States: A Nationwide Survey and Analysis.” International Journal of Entrepreneurship Education 1: 1-22.

Thornton, Mark. 1998. "Richard Cantillon and The Origins of Economic Theory.” Journal des Economistes et des Etudes Humaines: 61-74

Venkataraman, S. 1997. “The Distinctive Domain of Entrepreneurship Research,” in J. Katz and R. Brockhaus, eds. Advances in Entrepreneurship, Firm Emergence, and Growth. Greenwich: JAI Press.

Williamson, Oliver E. 1985. The Economic Institutions of Capitalism. New York: Free Press.

Williamson, Oliver E. 1996. The Mechanisms of Governance. Oxford: Oxford University Press.

Witt, Ulrich. 1998a. "Imagination and Leadership: the Neglected Dimensions of an Evolutionary Theory of the Firm,” Journal of Economic Behavior and Organization 35: 161-177.

Witt, Ulrich. 1998b. “Do Entrepreneurs Need Firms?” Review of Austrian Economics 11: 99-109.

Xue, Jian-Hong, and Peter G. Klein. 2007. “A Latent-Variables Approach to Entrepreneurship.” Working Paper, Contracting and Organizations Research Institute, University of Missouri.

Yu, Tony. 2005. Firms, Strategies, And Economic Change: Explorations In Austrian Economics. Cheltenham, U.K.: Edward Elgar. 


\section{SMG - Working Papers \\ www.cbs.dk/smg \\ 2003}

2003-1: Nicolai J. Foss, Kenneth Husted, Snejina Michailova, and Torben Pedersen: Governing Knowledge Processes: Theoretical Foundations and Research Opportunities.

2003-2: Yves Doz, Nicolai J. Foss, Stefanie Lenway, Marjorie Lyles, Silvia Massini, Thomas P. Murtha and Torben Pedersen: Future Frontiers in International Management Research: Innovation, Knowledge Creation, and Change in Multinational Companies.

2003-3: Snejina Michailova and Kate Hutchings: The Impact of In-Groups and OutGroups on Knowledge Sharing in Russia and China CKG Working Paper.

2003-4: Nicolai J. Foss and Torben Pedersen : The MNC as a Knowledge Structure: The Roles of Knowledge Sources and Organizational Instruments in MNC Knowledge Management CKG Working Paper.

2003-5: Kirsten Foss, Nicolai J. Foss and Xosé H. Vázquez-Vicente: “Tying the Manager's Hands": How Firms Can Make Credible Commitments That Make Opportunistic Managerial Intervention Less Likely CKG Working Paper.

2003-6: Marjorie Lyles, Torben Pedersen and Bent Petersen: Knowledge Gaps: The Case of Knowledge about Foreign Entry.

2003-7: Kirsten Foss and Nicolai J. Foss: The Limits to Designed Orders: Authority under "Distributed Knowledge" CKG Working Paper.

2003-8: Jens Gammelgaard and Torben Pedersen: Internal versus External Knowledge Sourcing of Subsidiaries - An Organizational Trade-Off.

2003-9: Kate Hutchings and Snejina Michailova: Facilitating Knowledge Sharing in Russian and Chinese Subsidiaries: The Importance of Groups and Personal Networks Accepted for publication in Journal of Knowledge Management.

2003-10: Volker Mahnke, Torben Pedersen and Markus Verzin: The Impact of Knowledge Management on MNC Subsidiary Performance: the Role of Absorptive Capacity CKG Working Paper.

2003-11: Tomas Hellström and Kenneth Husted: Mapping Knowledge and Intellectual Capital in Academic Environments: A Focus Group Study Accepted for publication in Journal of Intellectual Capital CKG Working Paper.

2003-12: Nicolai J Foss: Cognition and Motivation in the Theory of the Firm: Interaction or "Never the Twain Shall Meet"? Accepted for publication in Journal des Economistes et des Etudes Humaines CKG Working Paper.

2003-13: Dana Minbaeva and Snejina Michailova: Knowledge Transfer and Expatriation Practices in MNCs: The Role of Disseminative Capacity.

2003-14: Christian Vintergaard and Kenneth Husted: Enhancing Selective Capacity Through Venture Bases. 


\section{4}

2004-1: Nicolai J. Foss: Knowledge and Organization in the Theory of the Multinational Corporation: Some Foundational Issues

2004-2: Dana B. Minbaeva: HRM Practices and MNC Knowledge Transfer

2004-3: Bo Bernhard Nielsen and Snejina Michailova: Toward a Phase-Model of Global Knowledge Management Systems in Multinational Corporations

2004-4: Kirsten Foss \& Nicolai J Foss: The Next Step in the Evolution of the RBV: Integration with Transaction Cost Economics

2004-5: Teppo Felin \& Nicolai J. Foss: Methodological Individualism and the Organizational Capabilities Approach

2004-6: Jens Gammelgaard, Kenneth Husted, Snejina Michailova: Knowledge-sharing Behavior and Post-acquisition Integration Failure

2004-7: Jens Gammelgaard: Multinational Exploration of Acquired R\&D Activities

2004-8: Christoph Dörrenbächer \& Jens Gammelgaard: Subsidiary Upgrading? Strategic Inertia in the Development of German-owned Subsidiaries in Hungary

2004-9: Kirsten Foss \& Nicolai J. Foss: Resources and Transaction Costs: How the Economics of Property Rights Furthers the Resource-based View

2004-10: Jens Gammelgaard \& Thomas Ritter: The Knowledge Retrieval Matrix: Codification and Personification as Separate Strategies

2004-11: Nicolai J. Foss \& Peter G. Klein: Entrepreneurship and the Economic Theory of the Firm: Any Gains from Trade?

2004-12: Akshey Gupta \& Snejina Michailova: Knowledge Sharing in Knowledge-Intensive Firms: Opportunities and Limitations of Knowledge Codification

2004-13: Snejina Michailova \& Kate Hutchings: Knowledge Sharing and National Culture: A Comparison Between China and Russia

\section{5}

2005-1: Keld Laursen \& Ammon Salter: My Precious - The Role of Appropriability Strategies in Shaping Innovative Performance

2005-2: Nicolai J. Foss \& Peter G. Klein: The Theory of the Firm and Its Critics: A Stocktaking and Assessment

2005-3: Lars Bo Jeppesen \& Lars Frederiksen: Why Firm-Established User Communities Work for Innovation: The Personal Attributes of Innovative Users in the Case of Computer-Controlled Music

2005-4: Dana B. Minbaeva: Negative Impact of HRM Complementarity on Knowledge Transfer in MNCs

2005-5: Kirsten Foss, Nicolai J. Foss, Peter G. Klein \& Sandra K. Klein: Austrian Capital 
Theory and the Link Between Entrepreneurship and the Theory of the Firm

2005-1: Nicolai J. Foss: The Knowledge Governance Approach

2005-2: Torben J. Andersen: Capital Structure, Environmental Dynamism, Innovation Strategy, and Strategic Risk Management

2005-3: Torben J. Andersen: A Strategic Risk Management Framework for Multinational Enterprise

2005-4: Peter Holdt Christensen: Facilitating Knowledge Sharing: A Conceptual Framework

2005-5 Kirsten Foss \& Nicolai J. Foss: Hands Off! How Organizational Design Can Make Delegation Credible

2005-6 Marjorie A. Lyles, Torben Pedersen \& Bent Petersen: Closing the Knowledge Gap in Foreign Markets - A Learning Perspective

2005-7 Christian Geisler Asmussen, Torben Pedersen \& Bent Petersen: How do we Capture "Global Specialization" when Measuring Firms' Degree of internationalization?

2005-8 Kirsten Foss \& Nicolai J. Foss: Simon on Problem-Solving: Implications for New Organizational Forms

2005-9 Birgitte Grøgaard, Carmine Gioia \& Gabriel R.G. Benito: An Empirical Investigation of the Role of Industry Factors in the Internationalization Patterns of Firms

2005-10 Torben J. Andersen: The Performance and Risk Management Implications of Multinationality: An Industry Perspective

2005-11 Nicolai J. Foss: The Scientific Progress in Strategic Management: The case of the Resource-based view

2005-12 Koen H. Heimeriks: Alliance Capability as a Mediator Between Experience and Alliance Performance: An Empirical Investigation Into the Alliance Capability Development Process

2005-13 Koen H. Heimeriks, Geert Duysters \& Wim Vanhaverbeke: Developing Alliance Capabilities: An Empirical Study

2005-14 JC Spender: Management, Rational or Creative? A Knowledge-Based Discussion

\section{6}

2006-1: Nicolai J. Foss \& Peter G. Klein: The Emergence of the Modern Theory of the Firm

2006-2: Teppo Felin \& Nicolai J. Foss: Individuals and Organizations: Thoughts on a Micro-Foundations Project for Strategic Management and Organizational Analysis

2006-3: Volker Mahnke, Torben Pedersen \& Markus Venzin: Does Knowledge Sharing 
Pay? An MNC Subsidiary Perspective on Knowledge Outflows

2006-4: Torben Pedersen: Determining Factors of Subsidiary Development

2006-5 Ibuki Ishikawa: The Source of Competitive Advantage and Entrepreneurial Judgment in the RBV: Insights from the Austrian School Perspective

2006-6 Nicolai J. Foss \& Ibuki Ishikawa: Towards a Dynamic Resource-Based View: Insights from Austrian Capital and Entrepreneurship Theory

2006-7 Kirsten Foss \& Nicolai J. Foss: Entrepreneurship, Transaction Costs, and Resource Attributes

2006-8 Kirsten Foss, Nicolai J. Foss \& Peter G. Klein: Original and Derived Judgement: An Entrepreneurial Theory of Economic Organization

2006-9 Mia Reinholt: No More Polarization, Please! Towards a More Nuanced Perspective on Motivation in Organizations

2006-10 Angelika Lindstrand, Sara Melen \& Emilia Rovira: Turning social capital into business? A study of Swedish biotech firms' international expansion

2006-11 Christian Geisler Asmussen, Torben Pedersen \& Charles Dhanaraj: Evolution of Subsidiary Competences: Extending the Diamond Network Model

2006-12 John Holt, William R. Purcell, Sidney J. Gray \& Torben Pedersen: Decision Factors Influencing MNEs Regional Headquarters Location Selection Strategies

2006-13 Peter Maskell, Torben Pedersen, Bent Petersen \& Jens Dick-Nielsen: Learning Paths to Offshore Outsourcing - From Cost Reduction to Knowledge Seeking

2006-14 Christian Geisler Asmussen: Local, Regional or Global? Quantifying MNC Geographic Scope

2006-15 Christian Bjørnskov \& Nicolai J. Foss: Economic Freedom and Entrepreneurial Activity: Some Cross-Country Evidence

2006-16 Nicolai J. Foss \& Giampaolo Garzarelli: Institutions as Knowledge Capital: Ludwig M. Lachmann's Interpretative Institutionalism

2006-17 Koen H. Heimriks \& Jeffrey J. Reuer: How to Build Alliance Capabilities

2006-18 Nicolai J. Foss, Peter G. Klein, Yasemin Y. Kor \& Joseph T. Mahoney: Entrepreneurship, Subjectivism, and the Resource - Based View: Towards a New Synthesis

2006-19 Steven Globerman \& Bo B. Nielsen: Equity Versus Non-Equity International Strategic Alliances: The Role of Host Country Governance

\section{7}

2007-1 Peter Abell, Teppo Felin \& Nicolai J. Foss: Building Micro-Foundations for the Routines, Capabilities, and Performance Links 
2007-2 Michael W. Hansen, Torben Pedersen \& Bent Petersen: MNC Strategies and Linkage Effects in Developing Countries

2007-3 Niron Hashai, Christian G. Asmussen, Gabriel R.G. Benito \& Bent Petersen: Predicting the Diversity of Foreign Entry Modes

2007-4 Peter D. Ørberg Jensen \& Torben Pedersen: Whether and What to Offshore?

2007-5 Ram Mudambi \& Torben Pedersen: Agency Theory and Resource Dependency Theory: Complementary Explanations for Subsidiary Power in Multinational Corporations

2007-6 Nicolai J. Foss: Strategic Belief Management

2007-7 Nicolai J. Foss: Theory of Science Perspectives on Strategic Management Research: Debates and a Novel View

2007-8 Dana B. Minbaeva: HRM Practices and Knowledge Transfer in MNCs

2007-9 Nicolai J. Foss: Knowledge Governance in a Dynamic Global Context: The Center for Strategic Management and Globalization at the Copenhagen Business School

2007-10 Paola Gritti \& Nicolai J. Foss: Customer Satisfaction and Competencies: An Econometric Study of an Italian Bank

2007-11 Nicolai J. Foss \& Peter G. Klein: Organizational Governance

2007-12 Torben Juul Andersen \& Bo Berhard Nielsen: The Effective Ambidextrous Organization: A Model of Integrative Strategy Making Processes.

\section{8}

2008-1 Kirsten Foss \& Nicolai J. Foss: Managerial Authority When Knowledge is Distributed: A Knowledge Governance Perspective

2008-2 Nicolai J. Foss: Human Capital and Transaction Cost Economics.

2008-3 Nicolai J. Foss \& Peter G. Klein: Entrepreneurship and Heterogeneous Capital.

2008-4 Nicolai J. Foss \& Peter G. Klein: The Need for an Entrepreneurial Theory of the Firm.

2008-5 Nicolai J. Foss \& Peter G. Klein: Entrepreneurship: From Opportunity Discovery to Judgment. 